\title{
"Tatprovokation" - The Legal Issue of Entrapment in Germany and Possible Solutions
}

\author{
Franziska Görlitz, Juliane Hubert, Jasmin Kucher, Moritz Scheffer and Patrick Wieser*
}

(Received 1 November 2017; accepted 2 May 2018)

\begin{abstract}
Incitement by police officers is a well-known and often utilized police measure in the German investigation process. Yet, when it comes to prosecuting the perpetrators, a moral conflict arises. Should a State, bound by its own constitution and committed to protect its citizens, be allowed to incite or support a possible offender and afterwards judge on his or her wrongful actions? After Germany's higher courts had to deal with multiple cases of entrapped perpetrators, there has been a strong debate about the admissibility, requirements, and consequences of entrapment within the German legal system. International and national courts as well as scholars represent different legal standpoints in this regard. In particular, the approaches of the European Court of Human Rights and the German Federal Court of Justice differ significantly in their results. As Germany ratified the European Convention on Human Rights and therefore has to adhere to the European Court of Human Rights' ruling, an additional legal conflict arises. This article depicts and discusses the most relevant approaches to resolve this moral and legal conflict and satisfy both the need for effective prosecution and the procedural rights of the individual person subject to the act of entrapment. Additionally, recent legislative ambitions are presented.
\end{abstract}

\section{A. Introduction}

\section{The Issue of Entrapment}

Incitement by police officers is a well-known and often utilized police measure in the German investigation process. After Germany's higher courts had to deal with multiple cases of entrapped perpetrators, there has been a strong debate about the admissibility, requirements, and consequences of entrapment within the German legal system.

\section{Definition and Legal Basis}

German law does not explicitly delineate what constitutes entrapment (yet ${ }^{1}$ ), much less proscribe unlawful entrapment or set out the requirements for lawful acts of entrapment. As a repressive act of the police and the $S_{t a t e}{ }^{2}$, regulations for the admissibility of entrapment are derived from Germany's code of criminal procedure (StPO) $)^{3}$. Predominately, sections 110a through 110c StPO — which define and regulate the powers of a so-called verdeckter Ermittler (an undercover investigator) in Germany-apply in such cases. Section 110a(2) StPO, for example, provides a

\footnotetext{
${ }^{\star}$ This article is the result of a group assignment as part of a legal English program for German students at the FriedrichAlexander-Universität Erlangen-Nürnberg. At the time, the authors were enrolled as law students at this university.

${ }^{1}$ See infra Part E. Recent Legislative Ambitions.

${ }^{2}$ Bundesgerichtshofs [BGH] [Federal Court of Justice] Mar. 7, 1995, 1995 NeUE JURISTISCHE WoCHENSCHRIFT [NJW] $2237,2238$.

${ }^{3}$ STRAFPROZESSORDNUNG [STPO] [Code of Criminal Procedure].
} 
statutory definition of such undercover investigators who, in Germany, are subordinated to the prosecution as the head of the Ermittlungsverfahren (the preliminary investigative proceedings). Further, pursuant to section $110 \mathrm{c}(3)$ StPO, other regulations govern the undercover investigator's powers. Additional admissible measures for prosecution arise from this section, ${ }^{4}$ including the admissibility of entrapment. If the entrapment is not performed by an undercover agent-that is, not by a "publicly investigating officer" —_sections 160 and 161 StPO regulate its legal basis, for want of specific regulations.

Entrapment means that an agent of the State has incited a person, in a relevant way, to commit the crime of which he is then charged with. ${ }^{6}$ This could happen by strengthening the mens rea of the perpetrator or supporting his or her preparation of the actus reus. ${ }^{7}$ An agent of the State is thus defined as a member of a State investigation body and, accordingly, includes police officers or any person directed any such member thereof. ${ }^{8}$ The definition of entrapment also includes intensifying a crime by inciting the eventual perpetrator. ${ }^{9}$

\section{Constitutional Concerns Regarding Entrapment}

To begin, numerous critics claim that entrapment may run contrary to the Unschuldsvermutung (the presumption of innocence), which states that every person charged with a crime is innocent until he or she is convicted in a legally binding manner. ${ }^{10}$ Furthermore, a Rechtsstaat (a State bound by the rule of law) cannot act arbitrarily or provoke behavior that the State itself has prohibited. ${ }^{11}$ A social State in accordance with Article 20(3) of the Basic Law-Germany's constitution - should strengthen the lawfulness and good in its citizens and help them to abide by its rules instead of actively exposing them to the possibility of committing crimes. ${ }^{12}$ In addition, prosecuting someone for a crime that was effectively caused by State authorities runs counter to the function of modern criminal law, in which there is no punishment for mere intent without an actual reprehensible act-there is a lack of a so-called Handlungsunwert. ${ }^{13}$

\section{B. Entrapment as a Lawful and Legitimate Investigative Measure in Germany}

Although entrapment is a daily practice in Germany, its legitimacy is highly controversial and opinions on it differ widely.

\section{Opinions Stated in Legal Literature}

A number of voices in academic legal reference works consider entrapment as transcending the Sachverhaltsermittlung, the investigative process into the facts and circumstances of the case. This is the principle task and the overriding aim of such preliminary proceedings. It refers to the process of collecting all the requisite evidence against, and in favor of, the alleged criminal. Thus, several legal commentators see entrapment as merely inducing and facilitating the commission of additional crimes, as opposed to the gathering of information about previously

\footnotetext{
${ }^{4}$ Ralf GÜnther, Münchener Kommentar zur StPO $\$ 110 c, \S 29$ (Hans Kudlich ed., 1st ed. 2014).

${ }^{5}$ Werner Beulke, Strafprozessrecht 423 (2012).

${ }^{6}$ Bundesgerichtshofs [BGH] [Federal Court of Justice] Nov. 18, 1999, 45 ENTSCHEIDENGEN DES BUNDESGERICHTSHOFES IN STRAFSACHEN [BGHST] 321, 335.

${ }^{7}$ Sigrid Hegmann, Beck'scher OnLine-Kommentar zur StPO 8, \$110c (Jürgen Peter Graf ed., 25th ed. 2016).

${ }^{8}$ BGH STRAFVERTEIDIGER [STV] 129 (2016).

${ }^{9}$ GÜNTHER, supra note 4.

${ }^{10}$ Harald KöRner, Kriminalistik 451 (2002); Heribert Ostendorf \& Christian Meyer-Seitz, The Criminal Limits of the Police Lockspitzel Use, STV 73, 79 (1985).

${ }^{11}$ Harald KÖRner, Kriminalistik 453 (2002).

${ }^{12} I d$. at 449 .

${ }^{13}$ Ulrich Sieber, Legitimation und Grenzen von Gefährdungsdelikten im Vorfeld terroristischer Gewalt - Eine Analyse der Vorfeldtatbestände im "Entwurf eines Gesetzes zur Verfolgung der Vorbereitung von schweren staatsgefährdenden Gewalttaten," NEUE ZeITSCHRIFT FÜr STRAFRECHT [NSTZ] 353, 356 (2009).
} 
committed crimes. ${ }^{14}$ Accordingly, these voices stress that entrapping perpetrators that do not possess the actual mens rea for the commission of an offense, or that have not been suspected of such before the act of entrapment, cannot be permitted under section 161 StPO. Furthermore, those opposing entrapment state that inciting someone to commit a new crime in order to punish them for that specific conduct can never be justified by that person's previously committed offenses. ${ }^{15}$ Other opinions consider entrapment to be a generally permissible means to an end for effective prosecution; nevertheless, the criteria for its legitimacy differ. ${ }^{16}$

\section{Treatment Within the German Jurisdiction}

The jurisprudence in Germany insists on the fundamental legitimacy of entrapment. This is said to be a consequence of Article 20(3) of the Basic Law, ${ }^{17}$ in which the principle of a State under the rule of law, the Rechtsstaatsprinzip, is enshrined. It demands an effective prosecution. ${ }^{18}$ Its legitimacy, however, is limited by constitutional interests. Therefore, entrapment should only be allowed if the entrapped person is suspected of having committed similar crimes prior to the entrapment. Otherwise sections $160 \mathrm{ff}$ are not applicable. ${ }^{19}$ The Bundesgerichtshof (BGH; the German Federal Court of Justice) identified entrapment as a possible infringement of Article 6 of the European Convention on Human Rights (ECHR), ${ }^{20}$ but ultimately stated that such does not necessarily lead to a general prohibition against entrapment. ${ }^{21}$

Due to the decisions of the European Court of Human Rights (ECtHR), case law in Germany has shifted its position on entrapment considerably. Germany now distinguishes between admissible and inadmissible entrapment, ${ }^{22}$ linking different consequences to each. Entrapment is admissible when the perpetrator has previously been suspected of having committed serious offenses which are of a similar nature to those involved in the entrapment. ${ }^{23}$ The Bundesverfassungsgericht (the German Federal Constitutional Court) draws the distinction between admissible and inadmissible entrapment by balancing and evaluating the right to a fair trial, as stipulated in Article 6 ECHR, and the public interest in an effective criminal prosecution. ${ }^{24}$

\section{The Decisions of the ECtHR}

Article $6 \$ 1$ of the ECHR stipulates that every person has the right to a fair hearing by a tribunal. A conviction following an unlawful police incitement can constitute an infringement of this very right. As the ECtHR's jurisdiction is comprised of the interpretation and applicability of the Convention $^{25}$, it has addressed several instances of police incitement in the past.

\footnotetext{
${ }^{14}$ Frank Meyer \& Wolfgang Wohlers, Tatprovokation quo vadis - zur Verbindlichkeit der Rechtsprechung des EGMR (auch) für das deutsche Strafprozessrecht, JURISTENZEITUNG [JZ] 761, 761 (2015).

${ }^{15}$ Claus Roxin \& Bernd SCHÜnemann, StrafverfahrensRecht 8, § 37 (2017).

${ }^{16}$ Klaus Volk \& Armin Engländer, GRUNDKURS STPO 63, § 10 (2018); GÜNTHER, supra note 4, at 41, $\$ 110 \mathrm{c}$; Bertram Schmitt \& Lutz MeYer-Goßner, Strafprozessordnung: Gerichtsverfassungsgesetz, Nebengesetze und ERGÄNZENDE BestimMUngen 163 (59th ed. 2016); VolKer ERB, STPO $\$ 163$ (Löwe \& Rosenberg eds., 25th ed. 2004).

${ }^{17}$ GRUNDGESETZ [GG] [BASIC LAw], translation at http://www.gesetze-im-internet.de/englisch_gg/index.html.

${ }^{18}$ Bundesverfassungsgericht [BVerfGE] [Federal Constitutional Court] Nov. 11, 1984, 1985 NeUE JURISTISCHE WOCHENSCHRIFT [NJW] 1767.

${ }^{19}$ Hans Körner, Kriminalistik 451 (2002); Stefan Sinner \& Arthur Kreuzer, STV 115 (2000).

${ }^{20} 45$ BGHST 321 (323).

${ }^{21}$ SinNer \& KREUZER, supra note 19 , at 16.

${ }^{22}$ This notion was already demanded in Jörg KINZIG, STV 290 (1999).

${ }^{23}$ Bundesgerichtshof [BGH] [Federal Court of Justice] Jan. 19, 2016, 2016 NSTZ 232 [hereinafter Judgement of Jan. 19, 2016].

${ }^{24}$ Matthias Jahn \& Hans Kudlich, Juristische Rundschau [JR] 54, 58 (2016) (referring to BVerfG 2 BvR 209/14).

${ }^{25} \mathrm{See}$ Convention for the Protection of Human Rights and Fundamental Freedoms art. 32, Nov. 4, 1950. 213 U.N.T.S. 221.
} 
The most salient of these cases were Teixeira de Castro v. Portugal ${ }^{26}$, Bannikova v. Russia, ${ }^{27}$ and, most recently, Furcht v. Germany ${ }^{28}$, to name but a few. ${ }^{29}$ Following these decisions, it can be said that the ECtHR developed its own distinguished view on the delicate matter of police incitement, which eventually had a considerable effect on the German jurisdiction. ${ }^{30}$

\section{The Effect of ECtHR Rulings on German Law}

Before going into detail on the opinion of the ECtHR, one must consider the effect that comes from such a judgment and whether German national courts must respect the ECtHR's opinions in subsequent cases.

After Germany ratified the ECHR, it became ordinary statutory law, which is why it generally needs to be considered like any other statute passed in the German legal system. ${ }^{31}$ Therefore, it can conflict with other statutory provisions and even the German constitution itself. To ensure the binding nature of multilateral international treaties within the German legal system, the Bundesverfassungsgericht ruled that German courts must construe German law in a way that does not conflict with the domestic form of the international treaty. ${ }^{32}$ Under this principle, called völkerrechtsfreundliche Auslegung, the ECHR can even be utilized to interpret provisions of the German constitution. ${ }^{33}$ This principle aims to ensure a broad application of the ECHR, even in first-instance trials. When national courts fail to apply the ECHR correctly, the ECtHR may eventually intervene. The ECtHR, however, cannot overturn a national court's decision, and its powers primarily consist in assessing whether the Member State failed to comply with the ECHR and can, if necessary, grant monetary compensation pursuant to Article 41 of the ECHR. Furthermore, the ECtHR may not contact any national authorities regarding the execution of its judgment. ${ }^{34}$ Under Article 46 of EHCR, the Member States must nevertheless follow the ECtHR's decision. The specific violation must be discontinued and any recurrence should be avoided. ${ }^{35}$ Therefore, all national authorities, especially the courts, of the Member State involved must ensure that domestic law follows the ruling of the ECtHR. ${ }^{36}$ Only by doing so, can it be assured that the Member States comply with the ECHR as they agreed upon in Article 1 of the same.

\section{The ECtHR's General Perceptions on Entrapment}

As mentioned above, the ECtHR's decisions mostly revolve around the question of whether the criminal proceedings against a suspect as a whole were in breach of Article 6 of the ECHR. ${ }^{37}$ What the ECtHR does not stipulate is which legal consequence accompanies such an observation. ${ }^{38}$

\footnotetext{
${ }^{26}$ Teixeira De Castro v. Portugal App. No. 25829/94 (Jun. 9, 1998), http://hudoc.echr.coe.int/.

${ }^{27}$ Bannikova v. Russia, App. No. 18757/06 (Nov. 4, 2010), http://hudoc.echr.coe.int/.

${ }^{28}$ Furcht v. Germany, App. No. 54648/09 (Oct. 23, 2014), http://hudoc.echr.coe.int/.

${ }^{29}$ For a broad overview of ECtHR decisions on the matter of entrapment, see Robert Esser, Lockspitzel und V-Leute in der Rechtsprechung des EGMR: Strafrechtliche Ermittlungen jenseits der StPO - außerhalb des Gesetzes? in ABSHIED VON DER Wahrheitssuche. TeXte und Ergebnisse des 35. Strafverteidigertages in BerLin 197, 198 et seq. (2012).

${ }^{30} I d$. at 205.

${ }^{31}$ Bundesgerichtshof [BGH] [Federal Court of Justice] June 10, 2015, 60 ENTSCHEIDUNGEN DES BUNDESGERICHTSHOFES IN STRAFSACHEN [BGHST] 276 [hereinafter Judgement of June 10, 2015]; Bundesverfassungsgericht [BVERFGE] [Federal Constitutional Court], Mar. 26, 1987, Neue JURISTISCHE WochensCHRIFT [NJW] 74, 358, 370.

${ }^{32}$ Bundesverfassungsgericht [BVERFGE] [Federal Constitutional Court], Oct. 14, 2004, NEUE JURISTISCHE WOCHENSCHRIFT [NJW] 111, 307, 317 [hereinafter Judgment of Oct. 14, 2004].

${ }^{33}$ Bundesverfassungsgericht [BVERFGE] [Federal Constitutional Court], May 4, 2011, NEUE JURISTISCHE WOCHENSCHRIFT [NJW] $128,326,366-70$.

${ }^{34}$ Robert Esser, STPO EGMR 219, $\$ 1068$ (Löwe \& Rosenberg eds., 26th ed. 2012); Assanidze v. Georgia, App. No. 71503/

01 (Apr. 8, 2004), http://hudoc.echr.coe.int/.

${ }^{35}$ EsSER, supra note 34, at 107); Assanidze, App. No. 71503/01; Judgment of Oct. 14, 2004 at 321, MN. 41.

${ }^{36}$ Judgment of Oct. 14, 2004 at 320, $\$ 66$.

${ }^{37}$ Furcht, App. No. 54648/09 at $\$ 46$; Teixeira De Castro, App. No. 25829/94 at $\$ 34$.

${ }^{38}$ The approaches regarding the question of which legal consequence would be most appropriate differ. See supra Part D. Legal Consequences and Solutions.
} 
The ECtHR stresses that the public interest in the prosecution of serious crimes cannot be a valid argument in favor of entrapment, ${ }^{39}$ and it therefore considers any kind of entrapment to be a breach of Article 6 of the ECHR. ${ }^{40}$ The ECtHR carries out a "substantive test of incitement" ${ }^{41}$ to assess whether the accused has been incited-entrapped. According to the ECtHR, police incitement occurs whenever the agent "exert[s] such influence on the subject as to incite the commission of an offence that would otherwise not have been committed." 42

Within this context, the ECtHR developed a number of criteria. ${ }^{43}$ It first asks whether the investigation had been essentially passive ${ }^{44}$ and if the authorities had good reasons to suspect criminal activity when they first approached the person. As regards the latter, it can be particularly relevant to determine whether the suspect has a criminal record or if there have been preliminary investigations which would indicate a predisposition to his involvement in a particular criminal activity. To elaborate, even the fact that a suspect can obtain drugs in short notice and is familiar with the correlating prices can be of significance. The possibility that the suspect was pressured by the police into taking part in criminal activities also has to be considered. When the State's agent goes as far as making a second offer to the suspect after the suspect's initial refusal-especially a higher offer-or appealing to the person's compassion, the existence of entrapment is affirmed. ${ }^{45}$

Nevertheless, the ECtHR's examination of whether the proceedings were fair is not limited to the undercover police activity, but also includes the subsequent criminal trial. When the accused claims that he was incited by police agents-and the claim is not evidently improper-the prosecution must submit evidence that there was no entrapment involved. ${ }^{46}$ In summary, it can be said that the ECtHR examines the applicant's right to fair proceedings pursuant to Article $6 \$ 1$ of the ECHR on two separate levels: Level one consists of the "substantive test of incitement" regarding the entrapment itself, while level two refers to the subsequent proceedings at the national courts. ${ }^{47}$

Nevertheless, not everyone shares the ECtHR's opinion on entrapment and, with the definition of entrapment being so controversial, a number of different ways of dealing with it have arisen over time. The consequences of an inadmissible act of entrapment are probably even more controversial than the factual side of defining such an act.

As mentioned above, the ECtHR is not allowed to dictate a specific legal consequence that would have to follow any unlawful police incitement. Still, in its recent decision in Furcht $v$. Germany, the ECtHR found that a reduced sentence ${ }^{48}$ does not sufficiently compensate for the breach of Article $6 \$ 1$ of the ECHR. ${ }^{49}$ Moreover, the ECtHR stated that "any measure short of excluding such evidence [...] must also be considered as insufficient to afford adequate redress for a breach of Article $6 \$ 1$ [of the ECHR]." 50 This specific part of the decision sparked a lively debate among German legal commentators.

\footnotetext{
${ }^{39}$ Furcht, App. No. $54648 / 09$ at $\$ 64$.

${ }^{40} I d$. at $\$ 48$.

${ }^{41}$ Bannikova, App. No. $18757 / 06$ at $\$ 37$.

${ }^{42}$ Furcht, App. No. $54648 / 09$ at $\$ 48$; see also id.

${ }^{43}$ Furcht, App. No. $54648 / 09$ at $\$ 50$ et seq.

${ }^{44}$ Any measure exceeding the mere passive investigation of existing criminal activity would be unlawful.

${ }^{45}$ Furcht, App. No. 54648/09 at $\$ 52$; Bannikova, App. No. $18757 / 06$ at $\$ 47$.

${ }^{46}$ Ramanauskas v. Lithuania, App. No. 55146/14, $\$ 70$ (Feb. 20, 2018), http://hudoc.echr.coe.int/; Bannikova, App. No. $18757 / 06$ at $\$ 73$.

${ }^{47}$ Robert Esser, Lockspitzel und V-Leute in der Rechtsprechung des EGMR: Strafrechtliche Ermittlungen jenseits der StPO außerhalb des Gesetzes? in AbShIED VON DER WAHrheITSSUCHE. TeXTE UND ERGEBNISSE DES 35. STRAFVERTEIDIGERTAGES IN BERLIN 197, 201 (2012).

${ }^{48}$ First carried out by the Federal Court of Justice, see infra Part D.I.1.

${ }^{49}$ Furcht, App. No. 54648/09 at $\$ 69$.

${ }^{50} I d$.
} 


\section{Legal Consequences and Solutions}

Both before and after the recent ECtHR ruling, national jurisprudence and academic reference works have developed various approaches and arguments regarding how to correctly approach unlawful police incitement. The most established approaches will be illustrated below and, in order to do so, the following fictitious example will be applied to the different approaches to illustrate how they achieve different results.

$S$ is suspected of being involved in drug trafficking and of being part of a criminal organization that undertakes such deals. There is, however, no evidence that would allow proceedings to be instigated against $\mathrm{S}$. The police then decide to deploy an undercover agent, $\mathrm{A}$, who infiltrates the organization in order to gain incriminating evidence against $S$.

$\mathrm{S}$ is, in fact, not a part of the organization in question and was never involved in criminal activity whatsoever. He is, however, familiar with some of its members but does not know about their illegal business, even though he has his own suspicions. After A has gained S's trust, he approaches him and promises easy money in return for a simple drug deal. $S$ is not keen on the idea and wants to stay out of criminal activity. He tells A about these concerns. For days, A persistently urges $\mathrm{S}$ to perform the deal and promises a higher reward to $\mathrm{S}$. As $\mathrm{S}$ refuses, A appeals to his honor and calls him a coward. S finally gives in to A's efforts and meets $\mathrm{C}$ at a quiet place where the police apprehend both. Following this, $\mathrm{S}$ is charged with drug trafficking.

\section{Strafzumessungslösung—Fixing of Penalty Approach}

\section{Explanation}

The so-called Strafzumessungslösung - hereinafter referred to as the "sentencing solution"-was adopted in 1984 in a decision of the Bundesgerichtshof (BGH). ${ }^{51}$ In this landmark case, the BGH, for the first time, accorded profound attention to the question of how a successful act of entrapment, which did not comply with the principle of due process, is to be dealt with from a legal point of view. The BGH ruled in this respect that inadmissible entrapment could be "compensated for" by reducing the sentence of the accused person by a substantial amount. ${ }^{52}$

\section{Criteria}

Over the decades, the BGH has developed a vast number of criteria to be taken into account when it comes to assessing whether the entrapment was inadmissible or not. Among these criteria are, inter alia, reasonable initial suspicion against the entrapped person, the intensity and the purpose of the influence, as well as the willingness of the incited person to commit the offense. Each of these plays a significant role. ${ }^{53}$ Nonetheless, one should not be inclined to assume that the BGH has ever stipulated clearly defined conditions which, upon fulfilment, lead to the inadmissibility of an act of entrapment. Instead, it is only possible to infer from individual cases when the entrapment is inadmissible and, therefore, is to be taken into consideration as a substantial mitigating factor concerning the sentence. ${ }^{54}$

The most important mitigating factors can be divided into three categories: (1) Inadmissible, (2) long-term and sustainable influence, and (3) a minor degree of reprehensibility as a result of the offense. With regard to the first of these, close attention has to be paid to the question of whether the agent provocateur, rather than the incited person, dominated and directed the commission of the offense and therefore transgressed the principle of due process of law. ${ }^{55}$ Long-term

\footnotetext{
${ }^{51}$ Bundesgerichtshof [BGH] [Federal Court of Justice] May 23, 1984, 1984 NeuE JuRISTISCHE WochenSCHRIFT [NJW] 2300, 2302.

${ }^{52}$ Karsten Gaede, Fairness als Teilhabe - Das Recht auf Konkrete und wirksame Teilhabe durch Verteidigung GEMÄß ART. 6 EMRK 728-29 (2007).

${ }^{53}$ Bundesgerichtshof [BGH] [Federal Court of Justice] May 23, 1984, 1985 NEUE ZeITSCHRIFT FÜr STRAFRECHT [NSTZ] $131,132$.

${ }^{54}$ Klaus-Stephan von DanwitZ, StaAtliche Straftatbeteiligung 42 (2005).

${ }^{55}$ Bundesgerichtshof [BGH] [Federal Court of Justice] Sept. 23, 1983, 1984 NeUe Zeitschrift FÜr Strafrecht [NStZ] 78.
} 
and sustainable influence can be ascertained if the agent provocateur is constantly, and in a persistent manner, influencing the entrapped person. For instance, this would be the case if a person without previous criminal convictions is influenced by the agent provocateur over a period of several months and is only capable of committing the offense with the help of the agent. ${ }^{56}$ The last criterion refers to a situation when, as a result of the observation of the entrapped person by the police, nobody was actually endangered in the course of the entrapment. ${ }^{57}$

Academic reference works, however, focus on whether the influence by the agent provocateur impaired the free will of the suspect to a greater extent than the suspect is exposed to in his everyday life. ${ }^{58}$ According to a number of authors, the entrapment itself should also be inadmissible, and the sentence therefore reduced considerably, if the agent provocateur commits an offence in the course of his influence on the suspect-e.g., if he threatens the perpetrator. ${ }^{59}$

\section{Arguments in Favor of the Sentencing Solution}

With regard to the advantages of the sentencing solution, the high flexibility of this approach to inadmissible entrapment must be emphasized. The judge is able to find a case-by-case solution which appropriately satisfies the peculiarities of the case at hand. In order to reduce the sentence, it should be possible, according to the $\mathrm{BGH}$, to deny an aggravated form despite the fulfilment of a Regelbeispiel ${ }^{60}$ - a codified criterion which indicates the presence of an aggravated form of the offense-and to instead assume a minor degree of gravity of the offense. Moreover, the judge is entitled to stay the proceedings pursuant to sections 153 and 153a StPO in cases of a minor offense or in order to reduce the sentence to the minimum statutory sentence. All of these legal remedies enable judges to exercise their discretion and to reduce the sentence depending on the gravity of the inadmissible entrapment.

Be that as it may, following the sentencing solution cannot lead to an exemption from punishment in cases of serious offenses. ${ }^{61}$ This is justified by the fact that the accused has committed an offense and that he is-irrespective of the admissibility of the entrapment-guilty of this offense. ${ }^{62}$ Following the "doctrine of entrapment", American courts proceed similarly in cases of a felony and, therefore, come to the same result, which can also be seen as an argument advocating for the sentencing solution. ${ }^{63}$ Apart from that, every other solution which would ultimately lead to the acquittal of the wrongfully instigated person would not take into account the potential criminal intent of the suspect. In a case when an entrapped person is implementing criminal measures that go far beyond the original influence exerted by the agent provocateur, an acquittal would not match the responsibility of the instigated person. In this respect, the instigated person may, upon the exertion of influence, smuggle a much larger amount of drugs than the amount which was incited. ${ }^{64}$ This example, as well as the case in which a person dies during the course of the entrapment, illustrates that it is essential to create a solution which enables the judge to impose a sentence despite the inadmissibility of the entrapment.

\footnotetext{
${ }^{56}$ VON DANWITZ, supra note 54 , at $46-49$.

${ }^{57}$ VON DANwITZ, supra note 54 , at 49.

${ }^{58} I d$. at 53 .

${ }^{59}$ Hans Körner, Die Glaubwürdigkeit und die Strafbarkeit von V-Personen - die Strafbarkeit der provozierten Tat, STV 382, 385 (1982).

${ }^{60}$ See for example StrafGeSETZBUCH [STGB] [Penal Code] $\$ 243$, translation at https://www.gesetze-im-internet.de/stgb/ 243.html.

${ }^{61}$ NJW 1984, 2300 (2302); Patric Makrutzki, Verdeckte Ermittlungen im Strafprozess 256 (2000).

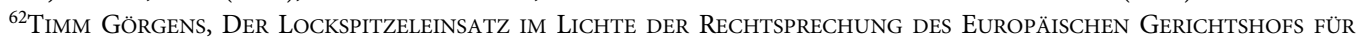
MENSCHENRECHTE 172 (2006).

${ }^{63}$ Patric Makrutzki, Verdeckte Ermittlungen im Strafprozess 256 (2000).

${ }^{64}$ GÖRGENS, supra note 62 , at 171-72.
} 


\section{Arguments Against the Sentencing Solution}

The high flexibility is not only regarded as the strongest argument advocating for the sentencing solution but also - in the absence of clearly stipulated criteria for mitigating factors - the strongest counterargument to this solution. The cogency of the argument propounded by opponents of the sentencing solution can be seen in the fact that neither statutory law nor case law have established non-judgmental criteria to decide whether the entrapment was inadmissible and, therefore, whether it is to be taken into consideration in terms of sentencing. In fact, all of the criteria mentioned above are to be seen as a basic guideline and are hard to ascertain beyond doubt due to their abstract nature. Moreover, there is no indication of how many of these criteria have to be present in order to render the entrapment inadmissible. ${ }^{65}$

Critics of the sentencing solution also emphasize that admissible, as well as inadmissible, entrapment is taken into consideration by reducing the sentence of the accused and that, as a consequence, no special attention is devoted to the inadmissibility of the entrapment. ${ }^{66}$ It has to be noted that the BGH does not differentiate between these types of entrapment by way of a divergent remedy but by reducing the sentence by a considerably higher extent in the case of inadmissible entrapment as compared to the case of admissible entrapment. ${ }^{67}$

The third crucial objection to the sentencing solution focuses on one criterion for the reduction of the sentence. According to the $\mathrm{BGH}$, the sentence has to be reduced if an infringement of a legally protected right could have been precluded from the outset as a consequence of constant observation by the police. Consequently, a potential reduced sentence would depend entirely on the successful observation by the police. This appears to be contradictory to the culpability principle because the culpability of the instigated person, which ultimately determines the sentence, would depend on circumstances which are beyond the sphere of influence of this person. ${ }^{68}$

Even though there are many more counterarguments to the sentencing solution, the aforementioned points are to be seen as the most conclusive and are therefore intended to give an illustrative insight into the problems with this approach.

\section{Application to the Fictitious Case}

Returning to the fictitious example, A has not only urged $\mathrm{S}$ to perform the deal but also influenced him persistently for days. This clearly shows that the exertion of pressure by the agent provocateur possessed a long-term and sustainable quality and was, therefore, inadmissible. Based upon this result, the judge would have to reduce the sentence considerably. When the instigated person has not acted beyond the original influence by the agent provocateur, a reduction of the sentence to the minimum statutory sentence would appear appropriate.

\section{Beweisverwertungsverbot-Inadmissibility of Evidence}

Regarding the above-mentioned sentencing solution, various legal commentators criticize the fact that a reduction in sentence cannot compensate for the fact that the State, whose duty it is to prevent criminal offenses, acts inconsistently by inciting the accused to carry out the unlawful behavior.

\section{Requirements from the ECtHR}

The ECtHR - which considers entrapment an infringement on the right to a fair trial provided by Article $6 \S 1$ of the $\mathrm{ECHR}^{69}$ - tries to take this factor into account when it proposes that the deployment of an undercover agent should lead to the inadmissibility of evidence which was

\footnotetext{
${ }^{65}$ VON DANWITZ, supra note 54 , at $49-50$.

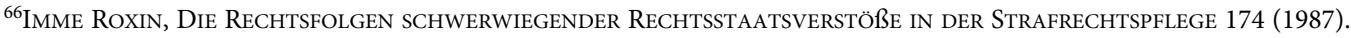

${ }^{67}$ MAKRUTZKI, supra note 63, at 257.

${ }^{68}$ Bodwin Blank, Die Strafbarkeit der vom agent Provocateur gesteuerten Tat 158-59 (1987).

${ }^{69}$ See supra Part C. The Decisions of the ECtHR.
} 
obtained as a result of the entrapment. ${ }^{70}$ This approach was specified in the decision of Furcht $v$. Germany ${ }^{71}$, whereby the court stated that "for the trial to be fair ... all evidence obtained as a result of police incitement must be excluded or a procedure with similar consequences must apply ..."72

\section{Inadmissibility of Evidence Under German Law}

The question as to whether evidence gained as a result of entrapment should be categorically excluded in court leads to several difficulties concerning the structure of German procedural law and the legal consequences of such a measure.

\subsection{The Distinction Between Obtaining and Utilizing Evidence}

The approach for deducing the inadmissibility of evidence from its illegal obtainment coincides with the so-called "fruit of the poisonous tree doctrine," originating from Anglo-American law, which describes the ban on the utilization of evidence-fruit - that was obtained under unlawful circumstances or through police misconduct-poisonous tree. ${ }^{73}$ Following this rule, all evidence directly or indirectly gained through unjust entrapment by an undercover agent would not be admissible in court and, in many cases, for want of evidence, the suspect would not be able to be prosecuted.

In contrast to the Anglo-American legal system, German procedural law distinguishes between evidence which was gained under unlawful circumstances (Beweiserhebung) and evidence which cannot be legally utilized (Beweisverwertung). ${ }^{74}$ The illegal obtainment of evidence does not, however, automatically render it inadmissible in court, as it is possible to use this evidence in the proceedings if the interest in the perpetrator's prosecution outweighs the protection of his individual rights. ${ }^{75}$

\subsection{Entrapment as an Illegal Method of Obtaining Evidence}

As a result of this distinction, one must consider whether the entrapment can be classified as an illegal method of obtaining evidence. Certain legal commentators in Germany argue that police incitement could be a prohibited method of investigation pursuant to section $136 \mathrm{a}(1) \mathrm{StPO} .{ }^{76}$ This section stipulates, inter alia, that the accused's freedom to make up his own mind and to manifest his will must not be impaired by deception when questioned by State agents. In addition to this, other commentators postulate that police incitement would even amount to a breach of Article 1 of the Basic Law. ${ }^{77}$

Regardless of whether the police incitement can be seen as an act of deception or not, whether the entrapment fulfils the criteria for obtaining evidence, which describes collecting incriminating information concerning a crime that has already been committed, is questionable. In contrast, the aim of entrapment is to provoke the suspect into the commission of a crime. The respective behavior of the State authorities therefore takes place in advance of the commission and is consequently not a method of collecting evidence but of creating the evidence by promoting the crime. ${ }^{78}$

\footnotetext{
${ }^{70}$ See Khudobin v. Russia, App. No. 59696/00, $\$ 133$ (Oct. 26, 2006), http://hudoc.echr.coe.int/; Teixeira De Castro, App. No. 25829/94 at $\$ 36$; Vanyan v. Russia, App. No. 53203/99, $\$ \$ 46-47$ (Dec. 15, 2005), http://hudoc.echr.coe.int/.

${ }^{71}$ Furcht, No. App. 54648/09.

${ }^{72} I d$. at $\$ 64$.

${ }^{73}$ This doctrine was first described in Silverthorne Lumber Co v. United States, 251 U.S. 385 (1920); later named by Justice Felix Frankfurter in Nardone $v$ United States, 308 U.S. 338 (1939); see also NikLaus Schmid, Das AmERIKANISCHE STRAFVERFAHREN 114 (1986).

${ }^{74}$ Ulrich EISENBERG, BEWEISRECHT DER STPO 117 (2017).

${ }^{75}$ Entscheidungen des Bundesgerichtshofes in Strafsachen [BGHSt] [Federal Court of Justice] 19, 329; Claus Roxin \& Bernd Schünemann, STRAFVERFAHRENSRECHT 21, § 24 (2017).

${ }^{76}$ KLAus LÜDerssen, FS Peters 363; Thomas Fischer \& Heinrich Maul, Tatprovozierendes Verhalten als polizeiliche Ermittlungsmaßnahme NSTZ 7, 13 (1992); Ulrich Berz, Polizeilicher agent provocateur und Tatverfolgung, in JURISTISCHE SCHULUNG, 416-419 (1982).

${ }^{77}$ Horst Franzheim, Der Einsatz von Agents provocateurs zur Ermittlung von Straftätern, NJW 2014 (1979).

${ }^{78}$ Imme Roxin, Die Rechtsfolgen SCHWERWiegender RechtsstaAtSVERSTÖßE IN DER STRAFRECHTSPFlege 216 (1987).
} 
This notion problematically indicates that the result of the entrapment is not the compilation of single pieces of evidence related to the offense, but rather the offense itself as a whole, which should be excluded in court. ${ }^{79}$ This result contradicts the German law of evidence, which stipulates that only the respective single pieces of evidence-such as testimony-or a single method of obtaining evidence-like torture—can be subject to a ban on the utilization of evidence. ${ }^{80}$

\subsection{Inadmissible Utilization of the Obtained Evidence}

Because the inadmissibility of evidence cannot be justified by entrapment being an illegal method of obtaining evidence, a question arises as to whether it is not the obtaining of the evidence itself but rather the utilization thereof in court that may be inadmissible.

If the utilization of the entire evidence is to be prohibited, then the court must deal with it as if it did not exist, ${ }^{81}$ and, as a result of this reality, the ban on the utilization would have similar consequences as, for example, a procedural impediment. ${ }^{82}$ In such a case, there would be no reason why a trial should take place, especially if the trial would not only harm the accused's reputation ${ }^{83}$ but also involve the risk that the accused would be drawn into making a confession, separate from the circumstances surrounding the entrapment, that could then be used in court. ${ }^{84}$

Therefore, it does not seem plausible to argue for a ban on the utilization of evidence if, for example, a procedural impediment would also leave the accused unpunished without him undergoing burdensome and incriminating proceedings. In summary, reacting to entrapment through a total ban on the utilization of the evidence is, at least in part, incompatible with German procedural law and, moreover, it does not represent a satisfactory solution for the accused. Nevertheless, the German legal system is currently trying to implement the requirements of the ECtHR by not considering evidence which was directly obtained from entrapment. ${ }^{85}$

\section{Application to the Fictitious Case}

Following the foregoing approach, a court would not be allowed to utilize any evidence concerning the drug deal, including the undercover agent's testimony and the crime that was provoked. As a result, the accused would almost certainly be acquitted for want of evidence.

\section{Equal Criminal Liability of Agent and Perpetrator}

\section{Explanation}

A different approach is represented by the German criminal law professor and dogmatist, Roxin, who proposes to treat the undercover agent and the perpetrator in a similar manner. On the one hand, the entrapment could be classified as a "police experiment" without legal consequences for both the undercover agent and the suspect. ${ }^{86}$ This alternative should, for example, be referable in cases of drug crimes when the crime causes an abstract danger as opposed to infringing a legally protected right. ${ }^{87}$ On the other hand, suspect and agent could both be convicted of the respective crime, the suspect as the perpetrator and the agent as the instigator of the crime, ${ }^{88}$ taking into account that, pursuant to section 26 of the StGB, both are punished equally.

\footnotetext{
${ }^{79}$ Ingeborg Puppe, Verführung als Sonderopfer-Zugleich Besprechung BGH 2 StR 446/85, NSTZ 404, 404-05 (1986); Karlheinz Meyer, Anmerkung zu NStZ 1985, 131, NSTZ, 131-35 (1985).

${ }^{80} 45$ BGHST 321 (321-35).

${ }^{81}$ Hans-Heiner KueHne, Strafprozessrecht, 907, $\$ 54$ IV (2015).

${ }^{82}$ Jörg Kinzig, Bewung in der Lockspitzelproblematic nach der Entscheidung des EGMR: muss die Rechtsprechung ihre strikte Strafzumessungslösung verabschieden?, STV 288, 292 (1999); Meyer, supra note 79, at 131-35.

${ }^{83}$ Robert EsSER, STPO EGMR $1074 \$ 1068$ (Löwe \& Rosenberg eds., 26th ed. 2012).

${ }^{84}$ BayObLG, NStZ 527-28 (1999); criticized by Case of Ramanauskas, App. No. 74420/01 at $\$ 72$.

${ }^{85} \mathrm{See}$ Bundesverfassungsgericht [BVERFGE] [Federal Constitutional Court] Dec. 18, 2014, 2015 NeUE JURISTISCHE WoCHENSCHRIFT [NJW] 1083, para. 53 [hereinafter Judgement of Dec. 18, 2014].

${ }^{86}$ Claus Roxin \& Bernd Schünemann, StrafverfahrensRecht 305 (2017).

${ }^{87} I d$.
} 


\section{Criticism}

In contrast to other possible solutions, this approach also deals with the question of the culpability of the undercover agent. While the first alternative does not clearly specify how the suspect should remain unpunished, the conviction of suspect and agent contradicts the fact that, under German criminal law, the prosecution of the instigator requires intent concerning the commission of the crime. ${ }^{89}$ The aim of the undercover agent is not the realization of the crime but rather the conviction of the perpetrator. As a consequence, convicting the inciter is incompatible with German law.

\section{Application to the Case}

First, entrapment could be seen as an experiment without legal consequences and, therefore in the fictitious sample case above, $S$ and A would both remain unpunished. According to Roxin, this would be the preferable solution in a case of drug offenses. Second, S may be convicted of drug dealing whereas A is charged with the incitement to this offense, and consequently both are punished equally.

\section{Procedural Impediment: BGH II}

In a decision from 2015, ${ }^{90}$ the $2^{\text {nd }}$ Criminal Panel of the BGH substantially deviated from its wellestablished case law on entrapment and its consequences. For cases of unlawful entrapment, the judges consider a procedural impediment as mandatory in the sense that it is the only approach that is fully in line with the ECtHR decision in Furcht v. Germany.

\section{Background}

Just a few weeks before the aforementioned decision was published, the $1^{\text {st }}$ Criminal Panel of the $\mathrm{BGH}$ had once more confirmed its view that unlawful entrapment can be sufficiently redressed by a reduction in the sentence, despite the ECtHR's then-recent rather explicit disapproval of this specific approach. ${ }^{91}$ Citing 2014 case law from the Bundesverfassungsgericht, the $1^{\text {st }}$ Criminal Panel stated that a procedural impediment-if at all—can only be assumed in the "most exceptional cases" of police entrapment. ${ }^{92}$ In the underlying case, such an extreme instance was, according to the $\mathrm{BGH}$, not present.

The decision of the Bundesverfassungsgericht, which was cited, was, however, highly controversial in itself. Despite its knowledge of the Furcht decision, the Bundesverfassungsgericht decided not to rule on the constitutional complaints submitted, as these did not contain any merits and the constitutional issues at hand had already been resolved. ${ }^{93}$ They argued that only extreme cases of entrapment could result in a procedural impediment derived from the principle of due process of law under Article 20(3) of the Basic Law. ${ }^{94}$ This appears to entirely contradict the ECtHR's point of view, which is why the decision was, unsurprisingly, vehemently criticized. ${ }^{95}$

\section{The Approach of the BGH's $2^{\text {nd }}$ Criminal Panel}

In its decision, the $2^{\text {nd }}$ Criminal Panel of the $\mathrm{BGH}$ - led by the prominent Judge Thomas Fischerconcluded that "an unlawful entrapment carried out by members of [S] tate authorities ... generally

\footnotetext{
${ }^{88} I d$.

${ }^{89}$ Rudolf Rengier, Strafrecht Allgemeiner Teil 423 (2009).

${ }^{90}$ Judgement of June 10, 2015.

${ }^{91}$ Bundesgerichtshofs [BGH] [Federal Court of Justice] May 19, 2015, 60 ENTSCHEIDENGEN DES BUNDESGERICHTSHOFES IN STRAFSACHEN [BGHST] 238.

${ }^{92} I d . \$ 11$.

${ }^{93}$ Judgement of Dec. 18, 2014 at para. 28.

${ }^{94} \mathrm{Id}$. at $\$ 34$.

${ }^{95}$ Matthias Jahn \& Hans Kudlich, Rechtsstaatswidrige Tatprovokation als Verfahrenshindernis: Spaltprozesse in Strafsachen beim Bundesgerichtshof, 2016 JuRISTISCHE RundsCHAU [JR] 54, 54, 58 (2016); Christian Jäger, Polizeilich initiierter Tatendrang, JURISTISCHE ARBEITSBLÄTtER [JA], 473, 475 (2015).
} 
results in a procedural impediment." In their written opinion, the judges made clear that they no longer wanted to be bound by their own former case law. They argued that the ECtHR had been reviewing the sentencing solution as a specific way to afford redress for the breach of Article $6 \$ 1$ of the ECHR and therefore deemed it insufficient. ${ }^{96}$

A procedural impediment leads to a bar on the proceeding's continuation and the charges against the defendant must be dropped, thereby terminating the criminal proceedings. This approach has been discussed in academic legal texts ever since and has often been viewed as the only sufficient solution that can fully take into account the ECtHR's ruling, even before the decision in Furcht v. Germany. ${ }^{97}$

The decision also addresses the question of whether, and, to what extent, the ruling of the ECtHR is binding on German courts. It may be up to the Member States and their domestic courts to decide how to specifically guarantee a fair trial pursuant to Article $3 \S 1$ of the ECHR while taking into account the characteristics of national legal systems. ${ }^{98}$ Nevertheless, as they are bound by Article 20(3) of the Basic Law, German courts must consider the ECHR and the decisions of the ECtHR..$^{99}$ For want of a legitimate approach, the BGH-as the sentencing solution turned out not to be-then assessed the different approaches proposed by case law over the years.

In favor of a procedural impediment, the BGH found that an exclusion of the improperly obtained evidence cannot be a way out of the dilemma. ${ }^{100}$ If an exclusion simply prohibited allowing the agent provocateur's testimony in court, then there would most certainly be other evidence, such as the testimony of observing agents, that would result in proceedings no fairer than they would be if they proceeded through the provocateur's own testimony. Moreover, the question arises as to whether the suspect's confession is entirely colored, and thus captured, within the circumstances of the entrapment. Determining the reach of the exclusion of evidence would thus require a distinct differentiation between indirect and direct evidence which is simply not attainable. If, according to the $\mathrm{BGH}$, even indirect evidence was considered inadmissible, the exclusion of evidence would eventually resemble a procedural impediment.

An interesting, yet natural, logical progression of the BGH's ruling is the total reversal of the relationship between rule and exception as initially created by the Bundesverfassungsgericht - that is, that prior to such a ruling, only extreme cases could result in an impediment. The judges left open to interpretation whether there can be room for cases of entrapment in which redress for a breach of Article $6 ₫ 1$ of the ECHR can be accomplished other than by a procedural impediment. Nevertheless, they demurred, stating that any other measure would perhaps not be in line with the Furcht ruling. ${ }^{101}$

Usually, the jurisdiction of the Bundesverfassungsgericht is binding on any other court within the German jurisdiction pursuant to section 31(1) of the Federal Constitutional Court Act. ${ }^{102}$ The Bundesverfassungsgericht's decision, however, was not binding because it did not rule on the substance of the matter, but rather it rejected the case. ${ }^{103}$ Thus, the BGH's $2^{\text {nd }}$ Criminal Panel was free to diverge from the approach that the Bundesverfassungsgericht's decision had proposed.

\footnotetext{
${ }^{96}$ Judgement of June 10, 2015.

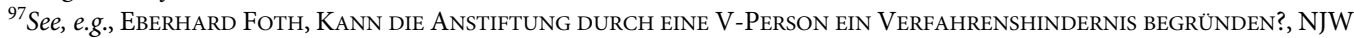
221-22 (1984); Robert Esser, in STPO EGMR, 442 (Löwe \& Rosenberg eds., $26^{\text {th }}$ ed. 2012); Hans Kudlich, Unzulässiger Einsatz eines Lockspitzels gegen einen Unverdächtigen, in JURISTISCHE SCHULUNG [JUS], 951-54 (2000).

${ }^{98}$ Judgement of June 10, 2015 at para. 45.

${ }^{99} \mathrm{Id}$. at para. 44 .

${ }^{100} I d$. at para. 52.

${ }^{101} \mathrm{Id}$. $\$ 58$.

${ }^{102}$ Bundesverfassungsgerichtsgesetz [BVerfGG] [Act on the Federal Constitutional Court] Mar. 12, 1951, Bundesgesetzblatt [BGBI]

${ }^{103}$ Matthais Jahn, Fair trial als strafprozessuales Leitprinzip im Mehrebenensystem, Zeitschrift für die gesamte Strafrechtswissenschaft, ZSTW 549, 600 (2015).
} 


\section{Reception and Evaluation}

In 2016, the $4^{\text {th }}$ Criminal Panel of the BGH had to decide a case in which, according to the judges, the police intervention had not crossed the line into unlawful police incitement. ${ }^{104}$ Nonetheless, it is worth mentioning that in its written opinion, the BGH stated that it considers itself obliged ex officio to pursue any material case that indicates the necessity for a procedural impediment following an act of unlawful entrapment. ${ }^{105}$ Hence, the $4^{\text {th }}$ Panel appears to agree with the solution that the $2^{\text {nd }}$ Panel proposed.

Even though most commentators appreciate the $2^{\text {nd }}$ Panel's novel ruling, they now admonish the fact that with the $2^{\text {nd }}$ and the $4^{\text {th }}$ panels on one side and the $1^{\text {st }}$ Panel on the other sideaccompanied by the Bundesverfassungsgericht — the issue now seems more controversial than ever and, therefore, urgently requires legislative intervention. ${ }^{106}$

\section{Application to the Fictitious Case}

When confronted with a case like the foregoing fictitious example, the BGH examines: (a) If entrapment occurred; and (b) if it was unlawful. When doing so, the BGH applies both its standard and the one developed by the ECtHR. Both would - in this case-lead to the conclusion that the investigative measures not only constituted entrapment but also unlawful entrapment and a breach of Article $6 \$ 1$ of the ECHR, precisely because of the way in which A operated as neither "essentially passive" (ECtHR) nor as limited to mere participation/cooperation (BGH). A took the initiative in contacting $S$, met $S$ 's initial refusal with a renewed offer with higher payment, and ultimately opposed him using the pressure of psychological stress. All of these facts suggest that unlawful entrapment occurred in this context. Beyond that, there were no good reasons for the police to assume that $\mathrm{S}$ was, in fact, involved in drug trafficking or at least planned to become involved in it in the future.

Therefore, the domestic court would have to stay proceedings against $S$ by establishing a procedural impediment. He would not be convicted for the drug trafficking that he was incited to commit.

\section{E. Recent Legislative Ambitions}

In addition to the BGH's new approach that takes into account the ECtHR ruling, there have been recent plans to insert entrapment into Germany's Code of Criminal Procedure, the StPO. This was proposed by a commission of criminal law experts who were instructed to advise on reforming the StPO in the near future. ${ }^{107}$ The commission's report defines entrapment (Tatprovokation) as "any way of incitement by an undercover agent, trusted person or other police agent provocateur which the [S] tate is responsible for." 108 The experts recommend codifying unlawful police incitement and establishing rules regarding the specific legal consequences. ${ }^{109}$ In their report, they mostly follow the ECtHR's strict policy and find that the principle decision as to whether to explicitly proscribe an act as entrapment needs to be made by the legislator. A legislative intervention is indeed long overdue as the StPO already extensively regulates all forms of undercover police measures. There are no good reasons why such a radical, extensive, and intrusive measure such as

\footnotetext{
${ }^{104}$ Judgement of Jan. 16, 2016.

${ }^{105}$ Id. $\$ 6$

${ }^{106}$ Guido Britz, Tatprovokation - eine kritische Bestandsaufnahme, JURIS - DIE MONATSSCHRIFT [JM] 123, 128 (2016); Jahn \& Kudlich, supra note 97, at 54, 64 .

${ }^{107}$ Federal Ministry of Justice and Consumer Protection, Report of the Expert Commission on the More Effective and Practicable Design of the General Criminal Proceedings and the Juvenile Court Proceedings (Oct. 2015), http:// www.bmjv.de/SharedDocs/Downloads/DE/PDF/Abschlussbericht_Reform_StPO_Kommission.pdf, 18, 84 et seq. (hereinafter Expert Commission); see also Jahn \& Kudlich, supra note 97, at 54, 63 et seq.

${ }^{108}$ See Expert Commission, supra note 107, at 84.

${ }^{109} \mathrm{Id}$. at 85 .
} 
entrapment should not be codified with the very same diligence. ${ }^{110}$ The same applies, of course, to the legal ramifications of any act of unlawful entrapment.

\section{F. Summary}

The use of undercover agents is, without doubt, a successful and wide-spread measure against serious and organized crime, especially in the field of drug-trafficking. Due to the complexity of the legal issue, there are numerous approaches to (a) what constitutes lawful entrapment, and (b) what consequences should follow an unlawful police incitement.

The first problem area is where to draw the line between legal investigation of crimes that are already planned — or in the making — and a situation in which State authorities "create" crimes that would not have occurred without their intervention. Each situation requires different legal consequences.

On the one hand, there is the undisputed social necessity to punish dangerous and serious crime as it occurs, and, on the other hand, as phrased by the ECtHR, a State under the rule of law cannot sacrifice the right to a fair trial for the sake of expedience. ${ }^{111}$ After year-long discussions, the ECtHR has made it clear that the BGH's former approach does not sufficiently compensate an accused for police entrapment. Even though the BGH did not adopt this ruling fully, the BGH finally gave in - at least in part - to the pressure to which it was exposed.

One way to solve the problem is, without a doubt, to codify the complex matter of entrapment within the StPO. The commission's report describes a framework of what this legislative move could look like. Nevertheless, it would certainly not be detrimental if the BGH adopted the ECtHR's ruling in its entirety in order to put a stop to unlawful police incitement once and for all.

\footnotetext{
${ }^{110}$ Also in favor of a codification of entrapment is Britz, supra note 106, at 128.

${ }^{111}$ Furcht, App. No. 54648/09 at $\$ 47$.
} 